\title{
Metastatic Skin Nodules -Is It Pointing Towards Aggressive Tumor Biology?
}

\author{
Authors \\ Dr Padhi Sanjukta MD, Dr Meher Papuji MD², Dr Pujari Lincoln MD ${ }^{3}$ \\ ${ }^{1}$ Associate Professor, Department of Radiation Oncology, A.H. Regional Cancer Centre, Cuttack \\ 2,3 Junior Resident, Department of Radiation Oncology, A.H. Regional Cancer Centre, Cuttack \\ Corresponding Author \\ Dr Sanjukta Padhi \\ Pithapur, Cuttack, Orissa \\ Email:drsanjuktapadhi@gmail.com,Tel \# 9437283032
}

\begin{abstract}
Background: Cutaneous metastasis is one of the rare occurrence in clinical practice. Cases with skin metastases are diagnosed to have stage IV disease and curative treatment is not intended in most of the cases. Due to the ease of accessibility for clinical and pathological examination its diagnosis and treatment plays great value.
\end{abstract}

Cases: Here we report nine cases with pathological diagnosis of skin metastases from different primaries from January 2015 to March 2016.

Conclusion: Development of multiple skin metastases indicates poor survival and co-existence of extracutaneous metastases makes survival even worse. Thorough metastatic workup and evaluation is necessary. Treatment is mostly palliative.

Key Words: Skin Nodules, Skin Metastases.

\section{INTRODUCTION}

Skin secondaries from various primary neoplasms are rare but is a pertinent findings in clinical practice $^{[1]}$. Breast, colon, and melanoma in women, and lung, colon, melanoma in men are commonly encountered primary lesions in clinics. Hematological malignancies like leukemias may also have clinical presentation with skin lesions ${ }^{[1,2]}$. Chest wall, abdomen and scalp are common sites for cutaneous metastases encountered. Detection of cutaneous metastatic disease necessitates prompt consultation with an oncologist for staging and management. ${ }^{[3]}$
The development of metastatic skin lesions is indicative of a poor prognosis and usually occurs with the presence of disseminated disease ${ }^{[4]}$. A retrospective study by Looking bill et al. showed a median survival of 18 months in patients with the same characteristics. ${ }^{[5]}$

Skin secondaries are reported to be of $0.7 \%-5 \%$ of cancer patients ${ }^{[6]}$, others have reported to be $9 \%{ }^{[7]}$, Metastatic skin lesions are rare in pediatric age group and it has different distribution in context with age and sex. ${ }^{[3]}$

Metastatic skin lesions are usually discovered on physical examination. The lesions may appear as nodules, ulcers or subcutaneous swellings which may be single or multiple, localized of dissemin- 
ated. Some tumors may have site predilection ${ }^{[2]}$. It may or may not be associated with other accompanying symptoms such as pain, hyperemia, edema etc.

Skin lesions may present upfront with diagnosis of primary disease or may develop after initial primary diagnosis ${ }^{[1]}$. Histopathological analysis is the mainstay of diagnosis, Immunohistochemistry in some cases help in diagnosis of primary disease. ${ }^{[3]}$ Any case of skin secondaries is said to have stage IV disease and treatment is mostly palliative.

\section{CASES}

Here we report nine cases of metastatic skin nodules of which most of them (eight cases) presented with upfront skin metastases. Out of nine cases three cases are of colorectal primary one each from cervix, breast, head \& neck, pancreas, testis and stomach primary. The relevant figures and composite table is given below.

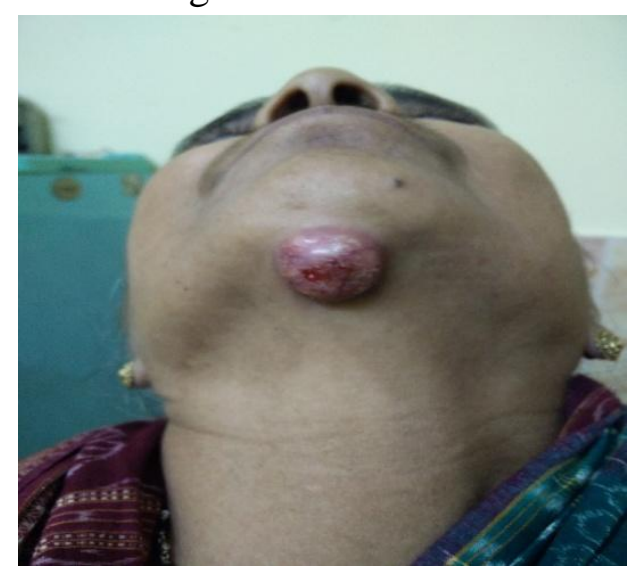

Fig - 1. - Showing submental nodule in a case of carcinoma cervix that presented upfront with bleeding per vagina and nodule over mentum

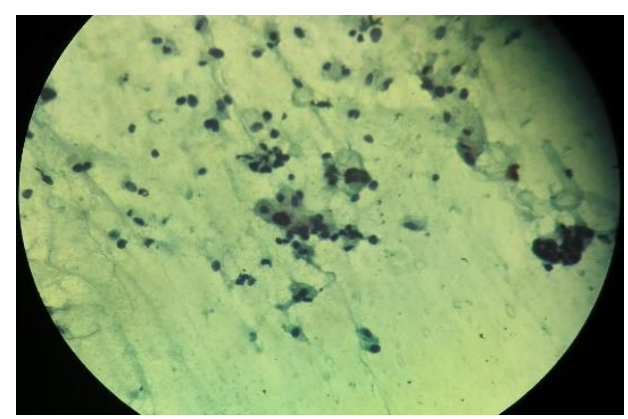

Fig-2, - FNAC from scalp nodule from the case of carcinoma rectum showing tumor cells arranged in singles and clusters in mucinous background. Some cells show intracellular mucin vacuole.

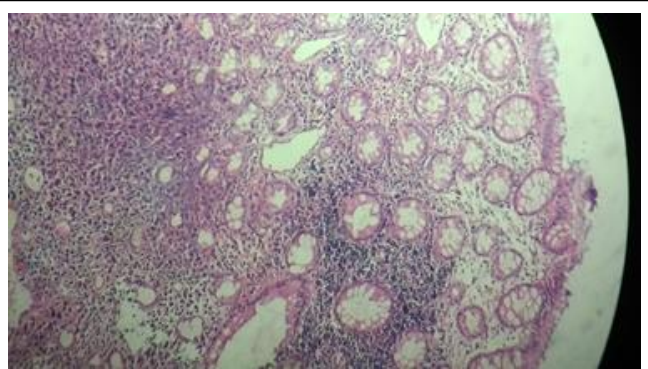

Fig-3- Histopathology: Rectal biopsy from the case of primary carcinoma rectum showing poorly differentiated adenocarcinomatous cells with numerous goblet cells

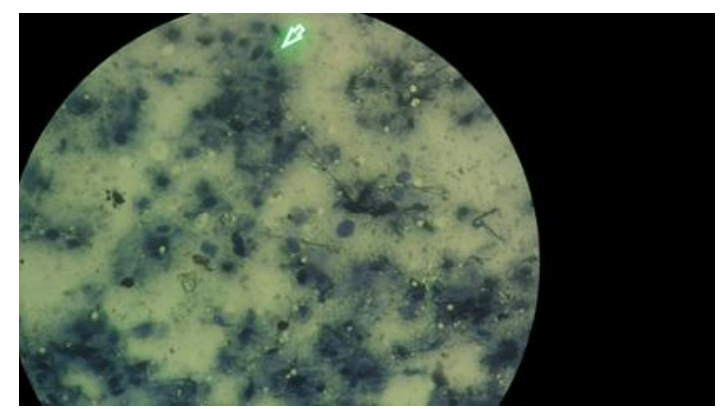

Fig-4- FNAC- From sub-mental nodule from a case of carcinoma cervix showing metastatic squamous cell carcinomatous cells with nuclear pleomorphism

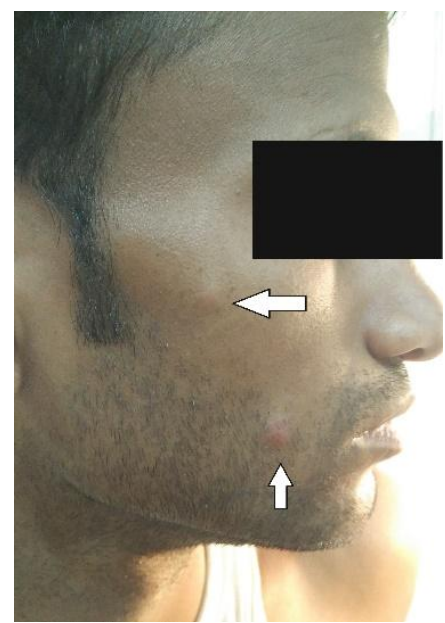

Fig.5- Showing $30 \mathrm{yr}$ old male of primary carcinoma rectum presenting with nodules over face(white arrows) and bleeding per rectum. 


\section{JMSCR Vol||04||Issue||11||Page 14242-14246||November}

Table-1, Showing cases of metastatic skin nodules with important clinicopathological features

\begin{tabular}{|c|c|c|c|c|c|c|c|}
\hline AGE/SEX & $\begin{array}{l}\text { CLINICAL } \\
\text { FEATURES }\end{array}$ & $\begin{array}{l}\text { PRIMARY/ } \\
\text { HISTOLOGY }\end{array}$ & $\begin{array}{l}\text { SITE OF } \\
\text { NODULE }\end{array}$ & $\begin{array}{l}\text { PATHOLOGY OF } \\
\text { METASTATIC } \\
\text { LESION }\end{array}$ & $\begin{array}{l}\text { TREATMENT } \\
\text { GIVEN }\end{array}$ & $\begin{array}{l}\text { OTHER } \\
\text { METASTATIC } \\
\text { SITE }\end{array}$ & $\begin{array}{l}\text { TIME OF } \\
\text { SKIN } \\
\text { METASTASE } \\
\text { S }\end{array}$ \\
\hline $50, F$ & $\begin{array}{l}\text { RECTAL } \\
\text { BLEEDING, } \\
\text { SCALP NODLUES }\end{array}$ & $\begin{array}{l}\text { RECTUM } \\
\text { Adenocarcinoma }\end{array}$ & SCALP & $\begin{array}{l}\text { METASTATIC } \\
\text { ADENOCARCINOMA }\end{array}$ & $\mathrm{CT}$ & LUNGS & UPFRONT \\
\hline $45 \mathrm{M}$ & DYSPHAGIA & $\begin{array}{l}\text { STOMACH } \\
\text { Adenocarcinoma }\end{array}$ & $\begin{array}{l}\text { ARM, CHEST } \\
\text { WALL }\end{array}$ & $\begin{array}{l}\text { METASTATIC } \\
\text { ADENOCARCINOMA }\end{array}$ & $\mathrm{CT}$ & BONE & AFTER CT \\
\hline $50, \mathrm{M}$ & $\begin{array}{l}\text { BONE PAIN, } \\
\text { ARM NODULE }\end{array}$ & $\begin{array}{l}\text { PANCREAS } \\
\text { Adenocarcinoma }\end{array}$ & RIGHT ARM & $\begin{array}{l}\text { METASTATIC } \\
\text { ADENOCARCINOMA }\end{array}$ & $\begin{array}{l}\text { PALLIATIVE } \\
\text { RT, CT }\end{array}$ & BONE & UPFRONT \\
\hline $30, \mathrm{M}$ & $\begin{array}{l}\text { RECTAL BLEEDING, } \\
\text { NODULES OVER } \\
\text { FACE, SCALP, } \\
\text { CHEST WALL }\end{array}$ & $\begin{array}{l}\text { RECTUM } \\
\text { Adenocarcinoma }\end{array}$ & $\begin{array}{l}\text { FACE, CHEST } \\
\text { WALL }\end{array}$ & $\begin{array}{l}\text { METASTATIC } \\
\text { ADENOCARCINOMA }\end{array}$ & $\mathrm{CT}$ & LUNGS & UPFRONT \\
\hline $55, \mathrm{M}$ & $\begin{array}{lr}\text { BONE } & \text { PAIN, } \\
\text { NODLUES } & \text { OVER } \\
\text { CHEST WALL, NECK, } \\
\text { ARMS }\end{array}$ & $\begin{array}{l}\text { COLON } \\
\text { Adenocarcinoma }\end{array}$ & $\begin{array}{l}\text { CHEST, } \\
\text { ABDOMEN, } \\
\text { ARM }\end{array}$ & $\begin{array}{l}\text { METASTATIC } \\
\text { ADENOCARCINOMA }\end{array}$ & $\begin{array}{l}\text { PALLIATIVE } \\
\text { RT }\end{array}$ & BONE & UPFRONT \\
\hline $50, \mathrm{~F}$ & $\begin{array}{l}\text { VAGINAL BLEEDING, } \\
\text { NODULE } \\
\text { MENTUM }\end{array}$ & $\begin{array}{l}\text { CERVIX } \\
\text { Squamous Cell } \\
\text { Carcinoma }\end{array}$ & $\begin{array}{l}\text { SUBMENTAL } \\
\text { AREA }\end{array}$ & $\begin{array}{l}\text { METASTATIC } \\
\text { SQUMAOUS CELL } \\
\text { CARCINOMA }\end{array}$ & $\mathrm{CT}$ & NONE & UPFRONT \\
\hline $35, \mathrm{M}$ & $\begin{array}{l}\text { SCROTAL SWELLING, } \\
\text { NODULES } \\
\text { CHEST, OVER } \\
\text { BACK }\end{array}$ & $\begin{array}{l}\text { TESTIS } \\
\text { Germ } \quad \text { Cell } \\
\text { Tumor }\end{array}$ & $\begin{array}{l}\text { CHEST, } \\
\text { BACK, ARMS }\end{array}$ & $\begin{array}{l}\text { METASTSTIC } \quad \text { GERM } \\
\text { CELL TUMOR } \\
\text { (High Grade) }\end{array}$ & $\mathrm{CT}$ & $\begin{array}{l}\text { LUNGS, LIVER, } \\
\text { DISTANT } \\
\text { LYMPH NODES }\end{array}$ & UPFRONT \\
\hline $40, \mathrm{~F}$ & $\begin{array}{l}\text { NODULE OVER } \\
\text { GLUTEL REGION }\end{array}$ & $\begin{array}{l}\text { BREAST } \\
\text { Invasive Duct } \\
\text { Cracinoma } \\
\end{array}$ & $\begin{array}{l}\text { GLUTEAL } \\
\text { REGION }\end{array}$ & $\begin{array}{l}\text { METASTATIC DUCT } \\
\text { CARCINOMA }\end{array}$ & $\mathrm{CT}$ & NONE & UPFRONT \\
\hline $35, \mathrm{M}$ & $\begin{array}{l}\text { NODULE } \\
\text { CHEST }\end{array}$ & $\begin{array}{l}\text { PYRIFORM } \\
\text { FOSSA } \\
\text { Squamous cell } \\
\text { Carcinoma }\end{array}$ & $\begin{array}{l}\text { CHEST } \\
\text { NODULE }\end{array}$ & $\begin{array}{l}\text { METASTATIC } \\
\text { SQUAMOUS } \\
\text { CARCINOMA }\end{array}$ & $\mathrm{CT}$ & NONE & UPFRONT \\
\hline
\end{tabular}

N.B.-CT-Chemotherapy, RT-Radiotherapy, M- Male, F- Female

\section{DISCUSSION}

Skin secondaries are one of the rare findings in clinical practice. Any primary neoplasm has potential for developing skin metastases ${ }^{[3]}$. Study by Aksoy $\mathrm{S}$ et al. showed that $0.7 \%$ and $10.4 \%$ of all patients with malignancies have skin metastases ${ }^{[8]}$.

The most common primaries associated with skin secondaries are breast, lung, colorectal ${ }^{[8]}$. In a retrospective study of 70 patients by Bansal et al showed that gastrointestinal tract $(46.7 \%)$ in males and breast $(32 \%)$ in females were the most common primary malignancy associated with such metastases. Abdomen including umbilical nodules is the frequent site for metastatic cutaneous nodule ${ }^{[9]}$ Clinically skin metastases present with painless nodules less commonly with ulcerative lesions. In all of our cases they presented with painless nodules. Sister Mary Joseph's nodules are metastatic skin nodules seen on abdominal wall in GI primary malignancies. In our series two of the cases of colorectal primary have nodules distributed over scalp, chest wall, face

Study by Schwartz et al described that metastatic skin lesions as the first sign of internal cancer. This is most commonly encountered in cancer of the lung, kidney, and ovary. ${ }^{[10]}$.

Cutaneous secondaries may only be the sign of malignancy in carcinoma of unknown primary ${ }^{[4]}$. Cutaneous metastasis may present upfront with diagnosis of primary or develop subsequently. Direct extension, lymphatic, intravascular dissemination or surgical implantation are common routes of spread. ${ }^{[7,8]}$

Histopathological study is the main line of diagnosis, IHC may be necessary to properly evaluate unknown primary. Imaging, serum markers may add additional information regarding disease stage. $^{[3]}$

Cases of skin secondaries are said to have advanced disease and treatment is mostly palliative to 
improve quality of life. Overall outcome is poor in terms of survival. High morbidity is seen in cases of skin metastases.

Chemotherapy may improve survival. Retrospective study of 141 cases by Chen et al showed that poor survival with cases of skin metastases but better prognosis is observed with breast primary. ${ }^{[11]}$ Lookingbill et al. ${ }^{[5]}$ in a retrospective study of 4,020 patients showed that, the mean survival ranged from 1 to 34 months depending on the primary tumor after detection of skin secondaries. Schoenlaub et al. ${ }^{[4]}$ retrospectively studied 200 cases of patients with evidence of cutaneous metastasis and found the median survival to be 6.5 months. Patients with an underlying colorectal primary with a median survival of 4.4 months ${ }^{[4]}$. Kaufmann et al suggested that metastatic spread of adenocarcinoma to the skin and subcutaneous tissue could be by lymphatic and haematogenous spread, by direct extension or by implantation during surgery ${ }^{[12]}$. With increasing incidence of malignancies clinicians are likely to come across metastatic skin nodules in clinics. They are of great values in search of primary diseaes.

\section{CONCLUSION}

Development of skin secondaries from internal malignancies is a rare findings. It occurs in context with advanced disease. Thorough clinical examination of patients for cutaneous nodules, metastatic workup and evaluation is necessary. Treatment is mostly palliative. Chemotherapy improves survival. Other modalities like surgery, radiotherapy, cryotherapy may be required with special indications.Is it pointing towards aggressive behaviour of tumor cells that need to be explored and addressed.

\section{REFERENCES}

1. Asuquo, M.E., Umoh, M.S. and Bassey, E.E. (2010) Cutaneous Metastatic Carcinoma: Diagnostic and Therapeutic Values. Advances in Skin \& Wound Care, 23, 77-80. http://dx.doi.org/10.1097/01.ASW.0000363504.92360.5f
2. Helm, T.N., Lee, T.C., Elston, D.M., Heymann, W.R., Schwartz, R.A. and Wells, M.J. (2014) Dermatologic Manifestation of Metastatic Carcinomas. http://emedicine.medscape.com/article/1101058-overwiew

3. Asuquo, M.E., Umana, A.N., Nwagbara, V.I.C., Nnoli, M. and Ugbem, T. (2016) Cutaneous Metastatic Disease: Case Series in a Tropical Setting. Case Reports in Clinical Medicine, 5, 25-31. http://dx.doi.org/10.4236/crcm.2016.51005

4. Schoenlaub P, Sarraux A, Grosshans E, Heide E, Cribier B: Survival after cutaneous metastasis: a study of 200 cases (in French). Ann DermatolVenereol2001, 128:13101315

5. Lookingbill DP, Spangler N, Helm KF: Cutaneous metastases in patients with metastatic carcinoma: a retrospective study of 4020 patients. J Am AcadDermatol 1993, 29:228-236.

6. Nesseris, I., Tsamakis, C., Gregoriou, S., Ditos, I., Christofidou, E. and Rogopoulos, D. (2013) Cutaneous Metastasis of Colon Adenocarcinoma: Case Report and Review of the Literature. Anais Brasileiros de Dermatologia, 88, 556- 558.

7. Pereina, W.A., Humaine, C.R., Silia, C.S. and Fermandos, L.H. (2011) Sister Mary Joseph's Nodule a Sign of Internal Malignancy. Anais Brasileiros de Dermatologia, 86, 118-120

8. Kilickap, S., Aksoy, S., Dincer, M., Saglam, E.A. and Yalcin, S. (2006) Cutaneous Metastasis of Signet Cell Carcinoma of the Rectum without Accompanying Visceral Involvement. Southern Medical Journal, 99, 1137-1139.

9. Bansal R ,Naik R., A study of 70 cases of cutaneous metastases from internal carcinoma, J Indian Med Assoc. 1998 Jan;96(1):102.

10. Schwartz RA, Cutaneous metastatic disease, J Am AcadDermatol. 1995 Aug;33(2 Pt 1):16182; quiz 1836 . 
11. Hu SC, Chen GS, Lu YW, Wu CS, Lan CC. J EurAcadDermatolVenereol. 2008 Jun;22(6):735-40. doi: 10.1111/j.14683083.2008.02590.x. Epub 2008 Feb 26.

12. Kauffman CL, Sina B. Metastatic inflammatory carcinoma of the rectum: tumor spread by three routes. Am J Dermatopathol 1997; 19: 528-532. 